\title{
cryptogamie Bryologie $2020 \cdot 41 \cdot 14$
Dimorphic sexual expression and anisospory in Homalothecium sericeum Schimp. s.l. (Brachytheciaceae) in Portugal
}

\section{Cecília SÉRGIO, Manuela SIM-SIMI \& César A. GARCIA}


Directeur de la publication / Publication diREctor: Bruno David,

Président du Muséum national d'Histoire naturelle

RÉDACTEUR EN CHEF / EDITOR-IN-CHIEF: Denis LAMY

ASSISTANTE DE RÉDACTION / ASSISTANT EDITOR: Marianne SALAÜN (bryo@cryptogamie.com)

Mise EN PAGE / PAGE LAYOUT: Marianne SALAÜN

RÉdACTEURS ASSOCIÉS / ASSOCIATE EDITORS

Biologie moléculaire et phylogénie / Molecular biology and phylogeny

Bernard GOFFINET

Department of Ecology and Evolutionary Biology, University of Connecticut (United States)

Mousses d'Europe / European mosses

Isabel DRAPER

Centro de Investigación en Biodiversidad y Cambio Global (CIBC-UAM), Universidad Autónoma de Madrid (Spain)

Francisco LARA GARCÍA

Centro de Investigación en Biodiversidad y Cambio Global (CIBC-UAM), Universidad Autónoma de Madrid (Spain)

Mousses d'Afrique et d'Antarctique / African and Antarctic mosses

Rysiek OCHYRA

Laboratory of Bryology, Institute of Botany, Polish Academy of Sciences, Krakow (Pologne)

Bryophytes d'Asie / Asian bryophytes

Rui-Liang ZHU

School of Life Science, East China Normal University, Shanghai (China)

Bioindication / Biomonitoring

Franck-Olivier DENAYER

Faculté des Sciences Pharmaceutiques et Biologiques de Lille, Laboratoire de Botanique et de Cryptogamie, Lille (France)

Écologie des bryophytes / Ecology of bryophyte

Nagore GARCÍA MEDINA

Department of Biology (Botany), and Centro de Investigación en Biodiversidad y Cambio Global (CIBC-UAM), Universidad Autónoma de Madrid (Spain)

COUVERTURE / COVER:

Extraits d'éléments de la Figure 3 / Extracts of the Figure 3

Cryptogamie, Bryologie est indexé dans / Cryptogamie, Bryologie is indexed in:

- Biological Abstracts

- Current Contents

- Science Citation Index

- Publications bibliographiques du CNRS (Pascal).

Cryptogamie, Bryologie est distribué en version électronique par / Cryptogamie, Bryologie is distributed electronically by:

- BioOne ${ }^{\circledR}$ (http://www.bioone.org)

Cryptogamie, Bryologie est une revue en flux continu publiée par les Publications scientifiques du Muséum, Paris Cryptogamie, Bryologie is a fast track journal published by the Museum Science Press, Paris

Les Publications scientifiques du Muséum publient aussi/ The Museum Science Press also publish: Adansonia, Geodiversitas, Zoosystema, Anthropozoologica, European Journal of Taxonomy, Naturae, Comptes Rendus Palevol, Cryptogamie sous-sections Algologie, Mycologie.

Diffusion - Publications scientifiques Muséum national d'Histoire naturelle

CP $41-57$ rue Cuvier F-75231 Paris cedex 05 (France)

Tél. : 33 (0)1407948 05 / Fax: 33 (0)1 40793840

diff.pub@mnhn.fr / http://sciencepress.mnhn.fr

(C) Publications scientifiques du Muséum national d'Histoire naturelle, Paris, 2020

ISSN (imprimé / print): 1290-0796 / ISSN (électronique / electronic): 1776-0992 


\section{Dimorphic sexual expression and anisospory in Homalothecium sericeum Schimp. s.l. (Brachytheciaceae) in Portugal}

Cecília SÉRGIO

Universidade de Lisboa, Museu Nacional de História Natural e da Ciência/ CE3C-Centre for Ecology, Evolution and Environmental Changes, Rua da Escola Politécnica, 58, 1250-102 Lisboa (Portugal) csergio@fc.ul.pt (corresponding author)

Manuela SIM-SIM

Universidade de Lisboa, Faculdade de Ciências de Lisboa, DBV, CE3C-Centre for Ecology, Evolution and Environmental Changes, C2, Campo Grande, 1749-016 Lisboa, and Museu Nacional de História Natural e da Ciência, Universidade de Lisboa, Rua da Escola Politécnica, 58, 1250-102 Lisboa (Portugal)

César A. GARCIA

Universidade de Lisboa, Museu Nacional de História Natural e da Ciência/ CE3C-Centre for Ecology, Evolution and Environmental Changes

Rua da Escola Politécnica, 58, 1250-102 Lisboa (Portugal)

Submitted on 6 June 2019 | Accepted on 15 July 2020 | Published on 6 October 2020

KEY WORDS Pleurocarpous moss, dioicous moss, sex strategies, heteromorphic gametophytes,
dwarf males, spore diameters.
Sérgio C. Sim-Sim M. \& Garcia C. A. 2020. - Dimorphic sexual expression and anisospory in Homalothecium sericeum Schimp. s.I. (Brachytheciaceae) in Portugal. Cryptogamie, Bryologie 41 (14): 197-204. https://doi.org/10.5252/ cryptogamie-bryologie2020v41a14. http://cryptogamie.com/bryologie/41/14

\section{ABSTRACT}

Among terrestrial plant species, male dwarfism (nannandry) is a unique feature of bryophytes, common in numerous dioicous pleurocarpous mosses. In this study, our objective was to describe and to elucidate the incidence of dwarf males in Portuguese populations of Homalothecium sericeum (Hedw.) Schimp and H. meridionale (M. Fleisch. \& Warnst.) Hedenäs. We also evaluated the occurrence of sporophytes and of dwarf males, in 150 selected samples from the LISU herbarium collection. The results showed that most samples are heteromorphic, with sporophytes, and include dwarf males, independent marginal male branches and/or caducous brood branches as vegetative propagules. The samples containing only independent male plants are infrequent. Anisospory was observed in both species, with a perceptible bimodal distribution of spore size in both species. Moreover, in Portugal no differences were found between the two species of this complex concerning the presence and relative position of male plants, the occurrence of anisospory, or the strategies exhibited by male plants, such as nannandry and caducous branches. 


\begin{abstract}
RÉSUMÉ
Dimorphie dans l'expression sexuelle et anisosporie chez Homalothecium sericeum Schimp. s.l. (Brachytheciaceae) au Portugal.

Parmi les espèces de plantes terrestres, le nanisme mâle est une caractéristique unique des bryophytes, commune à de nombreuses mousses pleurocarpes diö̈ques. Dans cette étude, notre objectif est de décrire et d'élucider l'incidence des mâles nains dans les populations portugaises de Homalothecium sericeum (Hedw.) Schimp et H. meridionale (M. Fleisch. \& Warnst.) Hedenäs. Nous avons également évalué la présence de sporophytes et de mâles nains dans 150 spécimens sélectionnés dans l'herbier de Lisbonne LISU. Les résultats montrent que la plupart des échantillons sont hétéromorphes, avec des sporophytes et comprennent des mâles nains, des branches mâles marginales indépendantes et/ou des branches caduques, aussi bien que des propagules végétatifs. Les échantillons contenant uniquement des plantes mâles indépendantes sont peu fréquents. L'anisosporie a été observée avec une distribution bimodale de la taille des spores, chez les deux espèces. De plus, au Portugal, aucune différence n'a été constatée entre les deux espèces de ce complexe en ce qui concerne la présence et la position relative des plantes mâles, la présence d'anisosporie ou les stratégies présentées par les plantes mâles telles que le nanisme et les branches caduques.
\end{abstract}

MOTS CLÉS

Mousse pleurocarpe, mousse dioïque, stratégies sexuelles, gamétophytes hétéromorphiques, mâles nains, diamètre des spores.

\section{INTRODUCTION}

The Portugese mossflora comprises four Homalothecium Schimp. species, of which the recently discovered Homalothecium meridionale (M. Fleisch. \& Warnst.) Hedenäs and H. sericeum (Hedw.) Schimp. s.s. are the most frequent (Hedenäs et al. 2014, Guerra et al. 2018). Homalothecium species are dioicous, and dwarf males were reported in the literature for this genus (Hedenäs $\&$ Bisang 2011). Male dwarfism is a notable condition of bryophytes that have the ability to form heteromorphic plants with males and females having very different morphologies, plus the male are smaller (dwarf male). It is estimated to occur in 10-20\% of all moss species and among the pleurocarpous mosses alone can occur in at least 22 families and about $75 \%$ of the studied pleurocarpous (Hedenäs \& Bisang 2011). Among them these authors listed eleven Homalothecium species with known dwarf males. The phenomenon of male dwarfism has received greater attention in H. laevisetum Lac. (Hofmann 1998), and especially in H. lutescens (Hedw.) H.Rob. (Rosengren \& Cronberg 2014; Rosengren et al. 2014). We have previously noticed the presence of dwarf males in Portuguese specimens of $H$. sericeum (Sérgio et al. 2003).

In some bryophyte species, spores produced in one sporangium are of two different sizes, which is termed "anisospory" (Glime \& Bisang 2017). Anisospory has been reported in a variety of mosses, not only in connection with male dwarfism, but has, however been suggested that the small spore fraction will give rise to male gametophytes (Ramsay 1979).

During further studies of Homalothecium material in LISU herbarium, we recorded sexual characteristics and or morphological features. We observed that specimens which had been previously identified as Homalothecium sericeum var. tenue Schlieph. ex G. Roth or were annotated with "small plants with long acuminate leaves, not fertile plants...” never exhibited sporophytes. These specimens were mainly from Atlantic areas, carried perigonial branches, i.e., they appeared to be male-expressing gametophytes, we cannot find females among these small plants and possibly come from male deciduous branches. Based on these observations, we suspected of a possible link between climate conditions, the sex expression, and morphological traits.

In this study we addressed the following questions in Homalothecium sericeum s.s. and $H$. meridionale:

- Do dwarf males always occur in female populations; i.e., are they obligate or facultative? Are there other reproductive strategies in this Homalothecium group?

- Is there a dominance of female samples over male plants/ colonies observed in the herbarium samples studied?

- Are the spores in these two species of two different sizes (anisospory)? In addition, are there aborted spores differentiated in the same capsule?

\section{MATERIAL AND METHODS}

\section{SAMPLING DESIGN}

All Portuguese specimens in LISU collection (c. 800) were revised for this study simultaneously during the work of identification of $H$. sericeum s.s. and $H$. meridionale (Sérgio et al. 2017). However, as $H$. meridionale and $H$. sericeum can only be separated by sporophyte characters, only a total of 240 samples with sporophytes were selected; $c$. $50 \%$ of the specimens corresponded to $H$. meridionale and $50 \%$ to $H$. sericeum s.s. The remaining specimens, more than 550 samples, did not exhibit sporophytes and were identified as $H$. sericeum s.l. (including some specimens corresponding to extremely small independent male plants).

But then to assess the proportion of specimens with female plants (with sporophytes) versus those with plants that are sterile and present male expression, specimens were selected based on a minimum sample area of $25 \mathrm{~cm}^{2}$ for $H$. sericeum s.l. So, out of 150 samples (Fig. 1) of geographically diverse Portuguese locations, we grouped the specimens as following: 1) heteromorphic plants (with female and male plants 
in independent tufts or in a mixed tuft, or else with female plants and the males on the margins); 2) the presence of dwarf males in female tufts; 3) tufts with male plants only; and 4) presence of caducous branches (mainly in male plants).

\section{SPORE TYPES AND MEASUREMENTS}

Scanning electron microscopy of spores of the two Homalothecium species was observed through JEOL-SM 5200 LV (at the Faculty of Sciences, University of Lisbon), based in capsula of four herbarium samples (as in the Fig. 3).

To estimate anisosporic spores within capsules, laboratory observations were made on 12 capsules of Homalothecium meridionale and $H$. sericeum (six specimens per species, one capsula per specimen). The selected capsules were always in a good maturation stage and operculated. Each dry capsule was sectioned to about half of the length and about $1 / 4$ of the spore's mass was observed. Circa 500 green spores were thus measured, as well as 20 aborted spores (brown and collapsed) per capsule. The measured spores were previously hydrated for at least 30 minutes and the measurements were made only on spherical, regularly-shaped and green spores. A binocular microscope with an immersion objective 100 (Olympus BX51) was used and a representative group of spores inside the same capsule was photographed (as in the Fig. 2I).

We tested if the proportion of frequency between the spore dimensions in the same capsule are homogeneous or deviated from the normal range as bimodal distribution mode (as in the Fig. 4). The readable histograms with frequency distributions was determined by using the function (two period of moving average) accessible in online Microsoft Excel version (2016).

\section{RESULTS}

The number of specimens of this Homalothecium group (H. seriserum s.l.) with capsules or remains of sporophytes and, simultaneously, with male plants or dwarf males, selected from LISU herbarium, is indicated in Figure 1. Most samples (97\%) are heteromorphic, having sporophytes and small dwarf males, independent marginal male branches, mixed tufts and/or caducous brood branches as vegetative propagules. The number of apparently sterile samples, without capsule but with perigonia is also presented (Fig. 1), as independent male plants (only 34\%).

From this study, the representative samples collected throughout the country (150 samples), we can conclude that most of them are heteromorphic (Fig. 1), with male and female plants in the same sample, although dwarf males were observed in c. $84 \%$ of the samples with sporophytes.

We found dwarf males on female plants of Homalothecium predominantly in the folds of leaves, the leaf axilla of older branches or mixed in the rhizoid tomentum or else at the base of stems (Fig. 2F, G).

As a note, the tendency to develop caducous branches is observed not only in the herbarium samples but also in the field, mainly in male plants. Such branches are abundant (c. 34\%) and are easily observed accumulated in the remains of paper sample packet (Figs 1; 2J).
Homalothecium sericium s.l.

150 selected samples from LISU herbarium

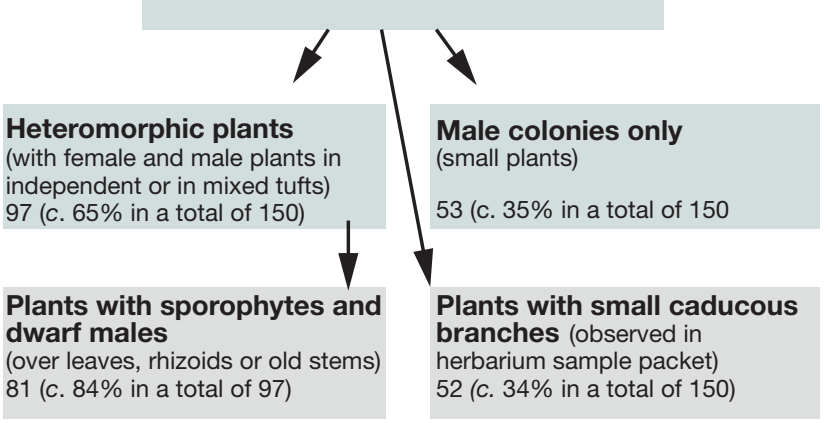

FIG. 1. - Synthesis of the observations of 150 selected samples of Homalothecium sericeum s.I. in LISU collection, showing proportion and percentage of 1) heteromorphic plants (female and male plants in independent tufts, mixed or marginal in female tufs; 2) the presence of dwarf males in female tufts (over leaves, rhizoids or old stems); 3) male tuffs only; and 4) tufts with plants with caducous branches, mainly in male plants. Boxes in dark grey: results with sexual expressions and box in light grey values of the presence of vegetative caducous branches.

Scanning microscopy observations did not reveal differences in spore diameter or wall structure between the two species (Fig. 3), but current findings support that in both species there are different spore sizes. However, the feature of walls in small spore is more finely muricate, giving a 'smoother' appearance in scanning observations.

The anisosporic condition was examined in the 12 selected capsules and the values are shown for both species (Fig. 4). The spores measured were mainly spherical, rarely very slightly ellipsoidal and are of three types: one, corresponding to small collapsed brownish spores, with a diameter range of 6 to $14 \mu \mathrm{m}$ in two species. The histograms presented follow the types called as double peaked distribution (bimodal distribution) showing two normal curves with two local maximum values.

These two types exhibit bimodal distributions in all histograms, with two peaks, the smaller of 16 to $18 \mu \mathrm{m}$, and the largest spores, ranging from 19 to $22 \mu \mathrm{m}$, although with maximum diameter values reaching 24 to $29 \mu \mathrm{m}$ in the two species (Fig. 4). Consequently, in individual capsules, spore sizes are typically bimodal, however with relative the proportions of the two modes (small and large) slightly variable in the different samples. In addition, the observed sizes of the two fractions varied slightly among the spores in the 12 analysed capsules. Nevertheless, no differences or insignificant dissimilarities in spore diameters were detected between the two species (Figs 3; 4).

\section{DISCUSSION}

\section{DO DWARF MALES CONSTANTLY OCCUR IN FEMALE} HOMALOTHECIUM POPULATIONS, OR ARE THERE OTHER REPRODUCTIVE STRATEGIES?

Our results suggest that dwarf males develop normally in the two Homalothecium species. However, the spores that develop in dwarf plants seems conditioned by the presence of living 


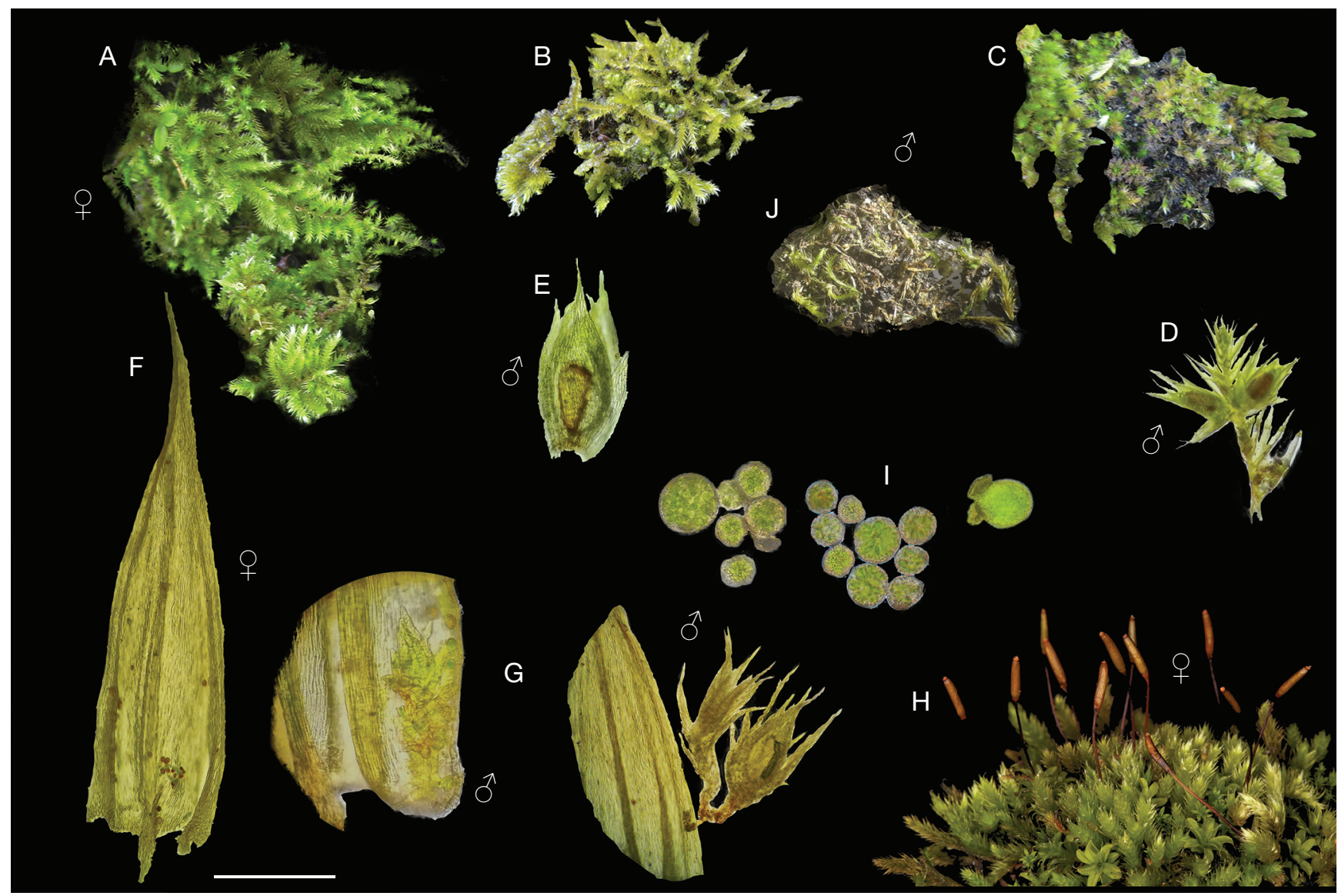

FIG. 2. - Synthesis of the observations of sexual expression in the two Homalothecium Schimp. species (H. sericeum (Hedw.) Schimp. s.s. and H. meridionale (M. Fleisch. \& Warnst.) Hedenäs) in Portugal (from LISU herbarium and/or field observations): A, female young colony without sporophytes, but with mixed small male plants; B, small independent male plants; C, independent male plants with caducous branches; $\mathbf{D}$, independent male with perigonia in small branch; E, detached perigonium with two antheridia; F, G, dwarf males attached as tiny epiphytes to the female leaf, originated directly from spores, generally observed acquiring basal rhizoids (G) and eventually originating independent male colonies (as B); $\mathbf{H}$, female plants with sporophytes and probably with dwarf males; I, green spores of two different sizes and aborted brown spores mixed (from capsules of LISU 262312; LISU 264096 and LISU 262054); J, part of a sample with caducous branches from a herbarium specimen. Scale bar: A, B, C, J, $0.8 \mathrm{~cm} ; \mathrm{D}, \mathrm{F}, 500 \mu \mathrm{m} ; \mathrm{E}, 300 \mu \mathrm{m} ; \mathrm{G}, 400 \mu \mathrm{m}$ and $600 \mu \mathrm{m} ; \mathrm{H}, 0.4 \mathrm{~cm} ; \mathrm{I}, \pm 50 \mu \mathrm{m}$.

female plants, as recognized recently in Homalothecium lutescens, as an adaptive background of nannandry (Rosengren et al. 2014; Rosengren \& Cronberg 2014). Also, in Portugal, no differences were found between the two species of the Homalothecium sericeum complex concerning the strategies and morphology observed for the male plants or the existence of nannandry (Figs $1 ; 2$ ) and the relative position of male plants in the sample tufts.

The caducous branches are apparently formed by male plants that develop small structures which spread out from mixed colonies which may or may not correspond to the growth of dwarf males. So, the presence of caducous branches is a complementary, though less well-known strategy observed in Homalothecium. In fact, the propagation through deciduous branches is a common strategy among pleurocarpous mosses, namely through morphologically differentiated branches, or through normal but easily detachable vegetative structures. Such structures were observed in both species, $H$. sericeum or $H$. meridionale, and very frequent in the studied samples (Figs $1 ; 2$ ). This strategy may facilitate the reproduction of these dioecious mosses.
We admit that sex ratio can be influenced not only by spore's germination and female availability, but also by climate and habitat conditions. The presence of male plants in independent patches is much more frequent in samples from Atlantic areas of Portugal; on the other hand, dwarves were only observed in colonies with sporophytes.

Thus, as conclusion, more than one of the considered reproduction strategies can be expected, separate or simultaneous and regardless of the species concerned (Homalothecium sericeum s.s. or in $H$. meridionale).

IS THERE A DOMINANCE OF FEMALE SAMPLES OVER MALE PLANTS/ COLONIES OBSERVED IN THE HERBARIUM SAMPLES STUDIED?

The reason for a predominance of female plants in dioicous bryophyte species is obscure but it might originate in events between meiosis and the protonemal stage (Longton \& Greene 1979). However, a study at 2009 (Korpelainen et al.) provides, for the first time in a moss species, a sex-specific DNA marker that allows reliable determination of gender and sex ratios.

In fact, the different sex strategies of Homalothecium are mainly connected to the sexual expression of male plants 

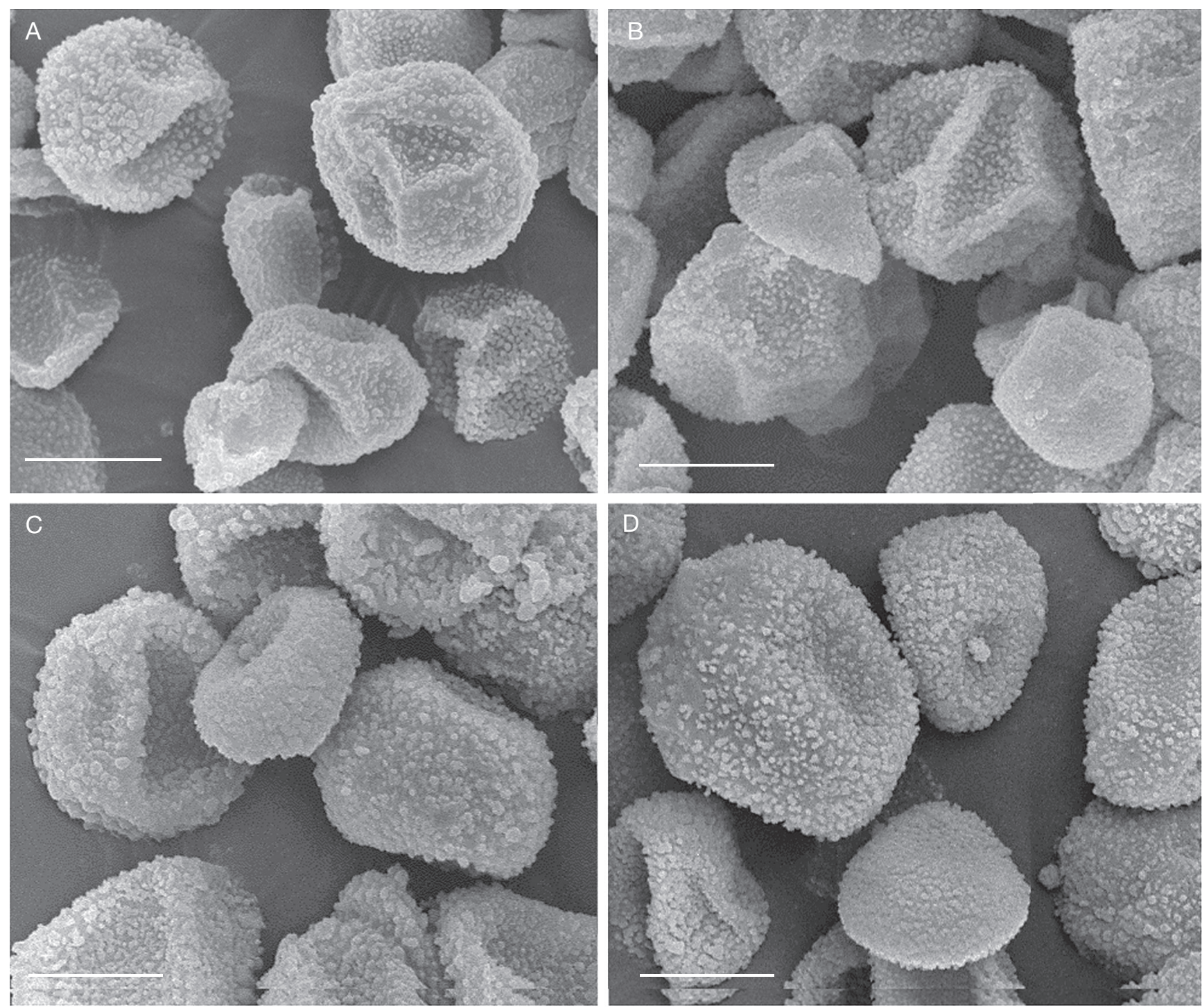

FIG. 3. - Spores photographed under scanning electron microscopy to reveal the anisosporic condition observed in individual capsules of two Homalothecium Schimp. species (H. sericeum (Hedw.) Schimp. s.s. and H. meridionale (M. Fleisch. \& Warnst.) Hedenäs) from herbarium samples: A, B, from capsules of $H$. sericeum s.s. (LISU 262054 and LISU 264096); C, D, from capsules of $H$. meridionale (LISU 265335 and LISU 266570). Scale bars: 10 $\mu$ m.

(Rosengren \& Cronberg 2015). According to models presented by Rydgren et al. (2010) for Hylocomium splendens (Hedw.) Schimp., female dominance is the predicted outcome of low to moderate fertilization success, explaining that in male dioicous bryophytes, the females must grow in close contact with males, to achieve fertilization (Halg 2016). The sexually dimorphic characters have been related to life strategy, as female plants must provide nutritional support to the "parasitic" sporophyte generation, a requirement that is not needed in males (Halg 2016).

Also, it has been shown for other bryophyte groups (Shaw \& Gaughan 1993), such as Ceratodon purpureus (Hedw.) Brid., that "female gametophytic clones formed significantly more biomass than male clones, and individual female shoots were more robust".

Under natural conditions, we observe a supremacy of female over male sexual expression either in Homalothecium sericeum s.s. or in $H$. meridionale. Although, not quantified in the Portuguese populations of Homalothecium, the dominance of female plants in relation to the male ones was evident, both in herbarium samples and during in field observations. Female plants appear to develop substantially higher biomass than male clones (Fig. 2A, B, H). However, from our field practice we recognise that dry areas (with less annual precipitation as in Mediterranean areas) appear to offer the best conditions for the development of dwarf males; in contrast, humidity, influenced by the Atlantic's proximity, has a positive effect on male spore reproduction and the development of independent male colonies (Fig. 2B-D). In some populations there is a greater incidence of male expression, mainly associated with shaded and protected microhabitats. The same is indicated for the development of reproductive structures in Fabronia ciliaris (Brid.) Brid. var. polycarpa (Hook.) W.R. Buck that is influenced by local 
Homalothecium sericeum s.s.
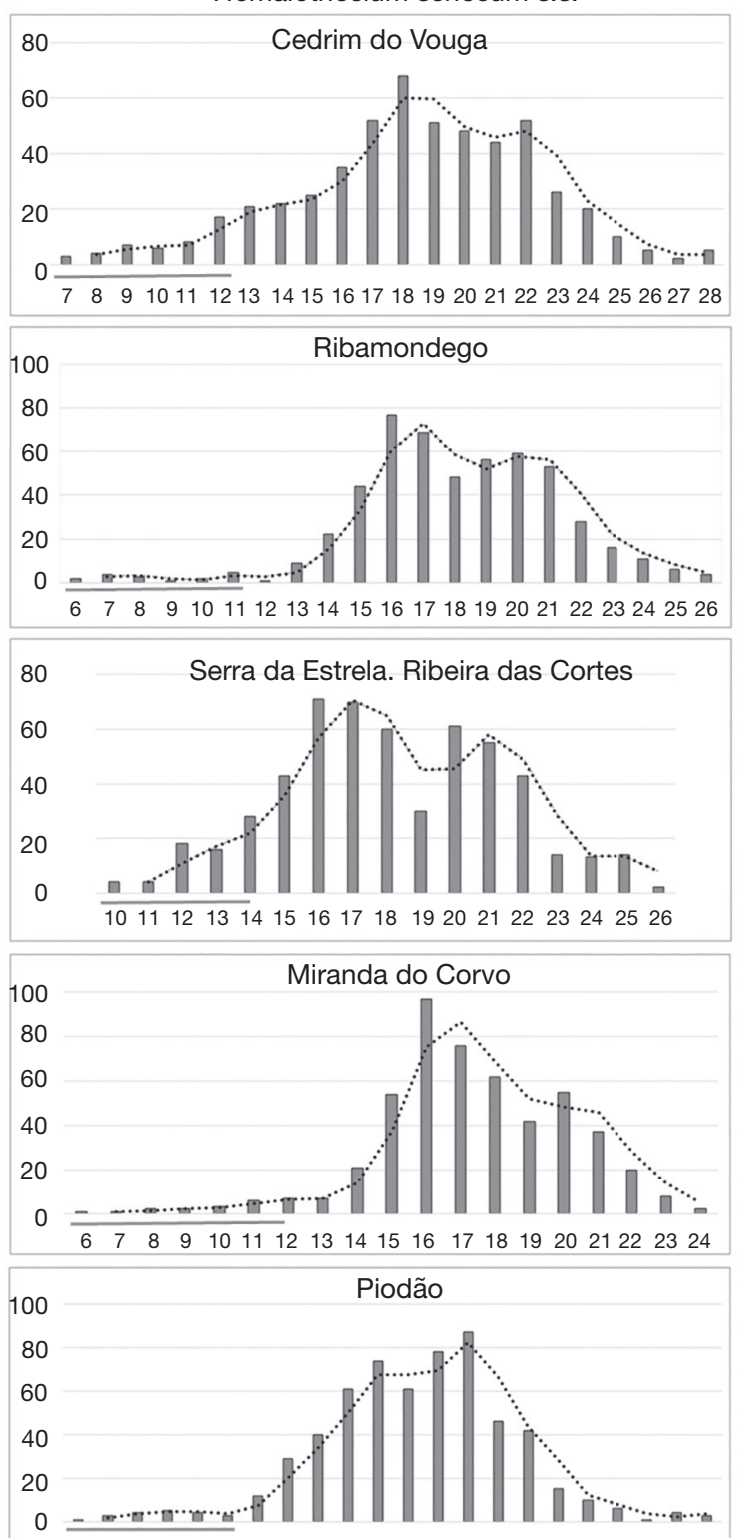

891011121314151617181920212223242526272829

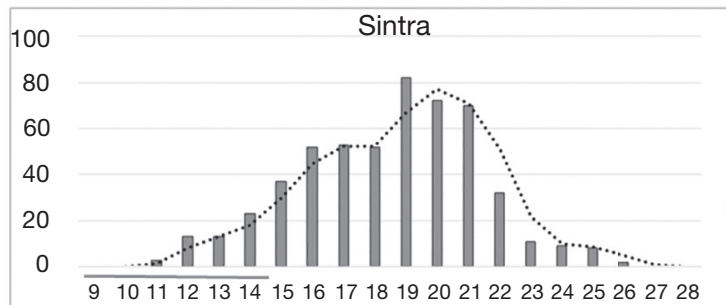

Homalothecium meridionale
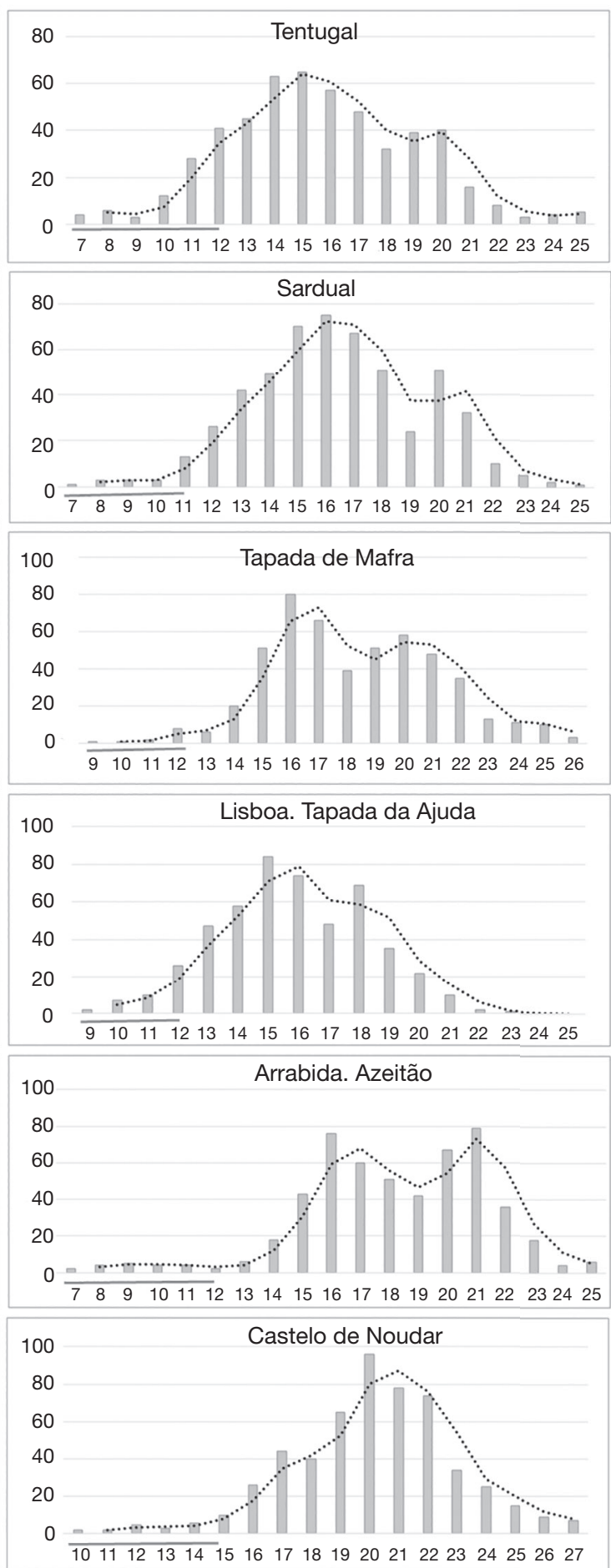

FIG. 4. - Graphical presentation of spore sizes from 12 different capsules of selected samples. Variation of spore sizes in six capsules of Homalothecium sericeum (Hedw.) Schimp. s.s (left graphics) and six capsules of $H$. meridionale (M. Fleisch. \& Warnst.) Hedenäs (right graphics). Numbers on the vertical axes indicate frequencies, and those on the horizontal axes indicate diameter values in $\mu \mathrm{m}$. The dashed line represents the tendency line bimodal distribution of diameter values. The dark grey horizontal bars in left side of each histogram, indicate the size range of collapsed spores, measured in the same capsule (capsules from LISU*collection, displayed sequentially for localities from the North to the South of Portugal).

rainfall, with high frequency of gametangia during the rainy season (Nunes et al. 2015). However, according to Bisang \& Hedenäs (2005) and Bisang et al. (2015), the phylogenetic history of a bryophyte and differences in reproductive costs may explain species-wide sex ratios better than current habitat influences, at least in some cases.

According to Bisang et al. (2017) sexual dimorphism may selectively favour female proliferation during some gameto- 
phyte phase as in other pleurocarpous mosses (Drepanocladus lycopodioides (Brid.) Warnst.). So, the dominance of females in the Homalothecium populations is in agreement with these authors and can be caused by diverse external influences, such as climate, during the gametophyte phase.

\section{ARE THE SPORES IN THESE DOUBLE SPECIES OF TWO} DIFFERENT SIZES (ANISOSPORY)? IN ADDITION, ARE THERE ABORTED SPORES DIFFERENTIATED IN THE SAME CAPSULE? Despite the normal homospory in bryophytes (isosporous, all spores equally sized), two ranges of spore sizes (anisospory) have been reported in dioicous species (Korpelainen 1998; Glime \& Bisang 2017). The anisosporous condition is uncommon in mosses (according to Glime \& Bisang 2017) but, during differentiation into two different spore sizes after meiosis seems to be less rare among dioicous bryophytes. On the other hand, anisospory has been linked to dwarfism in some groups of mosses (Ramsay 1979; Glime \& Bisang 2017). After sporogenesis, as usual, the spores will give two female and two male gametophytes, but the final ratio is generally strongly female-biased; however, the expressed sex rates can be a consequence of habitat or ecological conditions (Hedenäs \& Bisang 2015; Bisang et al. 2017). As represented in Figures 2-4, in Homalothecium sericeum s.s. and H. meridionale, the presence of spores of different sizes in the same capsule were clearly observed. As conclusion, the spore sizes display values with two peaks, as bimodal distribution, in all histograms presented.

We confirm that the variances found in spore sizes did not correspond to premature germination phenomena (false anisospory) as reported by Alfayate et al. (2013) for Leucodon canariensis (Brid.) Schwägr. or Cryptoleptodon longisetus (Mont.) Enroth. Indeed, the observed spores in Homalothecium are undivided and not germinated within the capsule (Fig. 2I).

We did not perform any germination experiment with spores of Homalothecium sericeum s.s. or $H$. meridionale, but this study shows that we are facing a typical phenomenon of anisospory. The spore size frequencies are grouped around two mean values, and, in addition, there is a fraction of aborted spores (Figs 2I; 3; 4). On the other hand, aborted spores were observed in all studied capsules, as also reported by Longton \& Greene (1979) in another pleurocarpous moss, Pleurozium schreberi (Brid.) Mitt., indicating that we are dealing with a case of amphispory (see Glime $\&$ Bisang 2017).

There are some observable differences between the green and brown spore fractions, not only in colour but also surface sculpture and in size. Consequently, there is reason to believe that the smallest brown spores (Fig. 2I) correspond to non-viable structures. However, more populations must be studied, and we suggest that assessment of spore germination in axenic cultures will be important to evaluate the development of each spore size group.

In order to fully understand the functional implications of sexual differentiation in this pleurocarpous group of mosses, a substantial amount of experimental or field work is required. In fact, there are other issues that need to be addressed, such as the existence of the spore capacity of Homalothecium sericeum s.s. to be able or not to develop dwarf males on female plants of $H$. meridionale. This can benefit a possible hybridization path between the two species. The identical has been referred to $H$. sericeum and $H$. lutescens (Rosengren \& Cronberg 2015) and may be an interesting approach, as both species, $H$. sericeum s.s. and $H$. meridionale, can be found in Portugal in the same areas.

On the other hand, different sexual strategies require attention, not only to determine their evolutionary factors in the face of a competitive disadvantage between the two sexes, but also to assess and facilitate the long-term conservation of these mosses, important for the natural environment.

\section{Acknowledgements}

The authors are grateful to Irene Bisang and Lars Hedenäs (Swedish Museum of Natural History, Stockholm) for their useful advices to develop the paper and valuable comments on the first manuscript. Rosa Maria Ros (University of Murcia) provided excellent observations and suggestions to improve the manuscript. Also, we are especially grateful to our colleague Graça Oliveira (CE3C) for useful remarks and kindly checking the English. We are grateful to Telmo Nunes for the assistance in the SEM micrographs. The authors wish to express their gratitude to all reviewers and to the editor for their valuable suggestions.

\section{REFERENCES}

Alfayate C., Ron E., Estébanez B. \& Pérez-Batista M. A. 2013. - Mature spores of four pleurocarpous mosses in the Canary Islands: Ultrastructure and early germination stages. The Bryologist 116: 97-112. https://doi.org/10.1639/0007-2745-116.2.097

BISANG I. \& HEDENÄS L. 2005. - Sex ratio patterns in dioecious bryophytes re-visited. Journal of Bryology 27 (3): 207-219. https:// doi.org/10.1179/174328205X69959

BisAng I., EhrléN J. J., Korpelainen H. \& HedENÄS L. 2015. No evidence of sexual niche partitioning in a dioecious moss with rare sexual reproduction. Annals of Botany, n.s. 116 (5): 771-779.

BisAng I., Hedenäs L. \& Cronberg N. 2017. — Can the meiotic sex ratio explain the sex ratio bias in adult populations in the dioecious moss Drepanocladus lycopodioides? Journal of Bryology 39 (2): 115-120

Glime J. M. \& BiSAng I. 2017. - Sexuality: Size and Sex Differences. Chapt. 3-3, in GLIME J. M. Bryophyte Ecology. 3-3-1 Volume 1. Physiological Ecology. Ebook sponsored by Michigan Technological University and the International Association of Bryologists. Last updated 31 March 2017 and available at http://digitalcommons.mtu.edu/bryophyte-ecology/. (Accessed on 1 June 2019).

Guerra J., Orgaz J. D. \& Sérgio C. 2018. - Homalothecium, in Guerra J., CANO M.J. \& BRugués M. (eds), Flora Briofitica Ibérica. Vol. VI. SEB/UMU: 138-148.

HALG D. 2016. — Living together and living apart: the sexual lives of bryophytes. Downloaded from http://rstb.royalsocietypublishing.org/ on November 27, 2018. (Accessed on 27 March 2019).

HedENÄs L. \& BisAng I. 2011. — The overlooked dwarf males in mosses - unique among green land plants. Perspectives in Plant Ecology, Evolution and Systematics 13 (2): 121-35. https://doi. org/10.1016/j.ppees.2011.03.001 
HEDENÄS L. \& BISANG I. 2015. - Are morphology and environment correlated with male dwarfism in pleurocarpous mosses? Arctoa 24: 362-374. https://doi.org/10.15298/arctoa.24.29

Hedenäs L., Désamoré A., Laenen B., Papp B., Quandt D., González-Mancebo J. M., Patiño J., Vanderpoorten A. \& STECH M. 2014. - Three species for the price of one within the moss Homalothecium sericeum s.l. Taxon 63 (2): 249-257. https:// doi.org/10.12705/632.16

HofMANN H. 1998. - A monograph of the genus Homalothecium (Brachytheciaceae, Musci). Lindbergia 23 (3): 119-159.

Korpelainen H. 1998. - Labile sex expression in plants. Biological Reviews 73: 157-180. https://doi.org/10.1017/ S0006323197005148

Korpelainen H., Bisang I., Hedenäs L. \& Kolehmainen J. J. 2009. - The First Sex-Specific Molecular Marker Discovered in the Moss Pseudocalliergon trifarium. The Journal of Heredity 99 (6): 581-587. https://doi.org/10.1093/jhered/esn036

LONGTON R. E. \& GREene S. W. 1979. - Experimental studies on growth and reproduction in the moss Pleurozium schreberi (Brid.) Mitt. Journal of Bryology 10 (3): 321-338. https://doi. org/10.1179/jbr.1979.10.3.321

Nunes E. M. B., Campelo M. J. De A. \& Maciel-Silva A. S. 2015. - Reproduçáo sexuada de Fabronia ciliaris (Brid.) Brid. var. polycarpa (Hook.) W.R.Buck (Fabroniaceae, Bryophyta) na caatinga: um estudo de caso no Boqueiráo de Onça, Brasil. Pesquisas Botânicas 67: 287-301.

RAMSAY H. 1979. - Anisospory and sexual dimorphism in the Musci, in Clarke, G. C. S. \& Duckett J. G. (eds), Bryophyte Systematics. Academic Press, London: 281-316.

Rosengren F. \& CRONBERG N. 2014. - The adaptive background of nannandry: dwarf male distribution and fertilization in the moss Homalothecium lutescens. Biological Journal of the Linnean Society 113: 74-84. https://doi.org/10.1111/bij.12332

ROSENGREN F. \& CRONBERG N. 2015. - Selective spore germination on shoots of Homalothecium lutescens, a moss with dwarf males. Biology Letters 11: 20150427. https://doi.org/10.1098/ rsbl.015.0427.

Rosengren F., Cronberg N., Reitalu T. \& Prentic H. C. 2014. - Sexual reproduction in the phyllodioicous bryophyte Homalothecium lutescens (Hedw.) H.Rob. in relation to habitat age, growth conditions and genetic variation. Journal of Bryology 36 (3): 200-208. https://doi.org/10.1179/1743282014Y.0000000114

Rydgren K., Halvorsen R. \& CRONBERG N. 2010. - Infrequent sporophyte production maintains a female-biased sex ratio in the unisexual clonal moss Hylocomium splendens. Journal of Ecology 98 (5): 1224-1231.

Sérgio C., Diogo A. L. \& Garcia C. 2003. - O género Homalothecium Bruch \& Schimp. em Portugal. Dados Taxonómicos e corológicos. In Notulae Bryoflorae Lusitanicae IX. 2. Portugaliae Acta Biologica 21: 282-285.

Sérgio C., Garcia C. A., Sim-Sim M., Vieira C., Hespanhol H., STOW S. \& GuerRa J. 2017 [2016]. — Homalothecium meridionale (M.Fleisch. \& Warnst.) Hedenäs: a distinct species from H. sericeum (Hedw.) Schimp. (Brachytheciaceae, Bryopsida) in The Iberian Peninsula. Journal of Bryology 39 (1): 1-7. https:// doi.org/10.1080/03736687.2016.1228274

SHAW A. J. \& GAUGHAN J. F. 1993 - Control of sex ratios in haploid populations of the moss, Ceratodon purpureus. American Journal of Botany 80: 584-591. https://doi.org/10.1002/j.1537-2197.1993. tb13844.x

Submitted on 6 June 2019; accepted on 15 July 2020 published on 6 October 2020.
APPENDIX 1. - Selected specimens from LISU* collections used for the photographs and spores measures. ( ${ }^{*}$ LISU - Herbarium Museu Nacional de História Natural e da Ciência. Universidade de Lisboa).

\section{Homalothecium sericeum (Hedw.) Schimp.}

Material. - Cedrim do Vouga, Bouça Nova, C. Sérgio, 2015 (LISU 262312); Gouveia, Ribamondego, C. A. Garcia \& C. Sérgio, 2011 (LISU 244806); Serra da Estrela, Ribeira das Cortes, C. A. Garcia, 2015 (LISU 265335); Miranda do Corvo, C. Sérgio, 2016 (LISU 266570); Piodáo, C. Sérgio \& C. A. Garcia, 2018 (LISU 266571); Sintra, Capuchos, C. Cacciatori, 2013 (LISU 257041).

\section{Homalothecium meridionale (M.Fleisch. \& Warnst) Hedenäs}

Material. - Coimbra, Tentúgal, C. Sérgio, 2016 (LISU 266053); Sardoal, Valhascos, C. Sérgio, 2015 (LISU 262054, LISU 178946); Mafra, Tapada, C. Sérgio, 2017 (LISU 266572); Lisboa, Tapada da Ajuda, E. Almeida \& V. Novais, 2011 (LISU s/no); Serra da Arrábida, Azeitão, C. Sérgio, 2016 (LISU 264096); Barrancos, Castelo de Noudar, C. Sérgio et al., 2004 (LISU 213400).

Other specimens of Homalothecium sericeum (Hedw.) Schimp. and H. meridionale (M.Fleisch. \& Warnst.) Hedenäs were listed for the Iberian Peninsula distribution (Sérgio et al. 2017). 